\title{
An efficient modification of ultra-stable $Y$ zeolites using citric acid and ammonium fluosilicate
}

\author{
Ke Qiao $\cdot$ Xuejin Li $\cdot$ Lifeng He $\cdot$ Xinmei Liu $\cdot$ \\ Zifeng Yan $\cdot$ Wei Xing $\cdot$ Lihong Qin • \\ Baoqin Dai $\cdot$ Zhihua Zhang
}

Received: 5 June 2014/ Accepted: 8 July 2014/Published online: 14 August 2014

(C) The Author(s) 2014. This article is published with open access at Springerlink.com

\begin{abstract}
The modification of commercial ultra-stable Y (USY) zeolite using citric acid (CA) and ammonium fluosilicate (AFS) was investigated. A series of factors including the concentration of CA and AFS, the volume ratio of $\mathrm{CA}$ and $\mathrm{AFS}$, adding rate of AFS, reaction time and temperature were studied to get the optimum operation condition. The pore structure, acid property and crystal structural of modified USY zeolite were characterized by a variety of means such as $\mathrm{N}_{2}$ adsorption, Fourier transform infrared spectroscopy, $\mathrm{NH}_{3}$-temperature programmed desorption and X-ray diffraction. The as-synthesized sample presents an increased secondary pore volume up to $0.20 \mathrm{~cm}^{3} / \mathrm{g}$ which accounts for $46.5 \%$ of the total pore volume, and appropriate acidity distribution as well as good crystallinity. In addition, the modified USY zeolite possesses a superhigh $\mathrm{Si} / \mathrm{Al}$ ratio of 25.7 which is more than twice higher than that of commercial USY zeolite. Furthermore, the hydrothermal stability of the modified samples meet the requirements of commercial catalysts for hydrocracking. Performance evaluation was carried out on a $200 \mathrm{~mL}$ fixed-bed single stage hydrogenation unit using Daqing VGO as feedstock. The $140-370{ }^{\circ} \mathrm{C}$ middle distillate yield is $67.78 \%$, and middle distillate selectivity can
\end{abstract}

K. Qiao · X. Li · L. He · X. Liu · Z. Yan $(\bowtie) \cdot$ W. Xing

State Key Laboratory of Heavy Oil Processing PetroChina Key

Laboratory of Catalysis, China University of Petroleum,

Qingdao 266580, China

e-mail: zfyancat@upc.edu.cn

X. Li

e-mail: 1xjupc@gmail.com

L. Qin · B. Dai · Z. Zhang

Daqing Petrochemical Research Center, PetroChina

Petrochemical Institute CNPC, Daqing 163714, China reach up to $80.76 \%$. Compared with commercial catalyst, the yield and selectivity are increased by 7.36 and $4.38 \%$, respectively.

Keywords USY zeolite - Modification · Citric acid · Ammonium fluosilicate

\section{Introduction}

In petroleum refining, hydrocracking of heavy hydrocarbons has been carried out to produce high quality middle distillate. Most of the conventional hydrocracking catalysts are dual functional catalysts which possess a hydrogenation-dehydrogenation function as well as an acidic function $[1,2]$. The activity of the hydrocracking catalysts depends largely on the support which is acidic in nature. In order to prepare a suitable hydrocracking catalyst, a good balance between the two functions has to be maintained [3]. The rapid molecular transfer from the hydrogenation site to the acid site is very important as it can avoid undesirable secondary reactions.

Y and ultra-stable Y (USY) zeolites have been commonly applied in hydrocracking to increase middle distillate yield due to their high specific surface area and tunable acid properties [4]. However, the performance of commercial USY (CUSY) is unsatisfying due to the lack of mesopores. As we all know, cracking is often limited by diffusion of reactants inside the micropore of zeolite. The mesoporous structure is more suitable for diffusion of reactants. This is because the external surface area of zeolite increases and thus reactants become more easily accessible to the catalytically active acid sites [5]. In addition, the hydrothermal stability of USY zeolite also needs to be improved to meet the requirement of 
hydrocracking. Moreover, high acidity tends to cause coking, which leads to catalyst deactivation. The catalyst deactivation will cause a reduction of product selectivity and quality. Therefore, the modification of USY zeolite is of great significance $[1,6]$.

Many researchers have reported that dealumination of Y zeolite can improve its thermal and hydrothermal stability, hydrophobicity and mesopore content [7, 8]. Dealumination can be accomplished by thermal or hydrothermal treatments [9], acids leaching [10], and chemical treatments with hexafluorosilicate or silicon tetrachloride [11-14]. Among these methods, hydrothermal treatment is the most frequently used on. The resulting materials, USY zeolites, being modified in the framework Si/Al ratio, structure and acidity, usually exhibit improved reactivity, selectivity and coking behavior for a catalytic reaction, which is of great interest to the petroleum industry. However, the pore size and acid distribution of the zeolites with hydrothermal treatment are unreasonable for meeting the needs of hydrocracking [15, 16]. Dealumination with inorganic acid can remove framework aluminum effectively when the $\mathrm{pH}$ is lower than 2.30 , indicating that the dealumination is proportional to the hydrogen ion concentration [17, 18]. On other hand, organic coordination reaction method shows a very attractive potential in remove of extra-framework aluminum (EFAL), because it can be operated in moderate reaction conditions, and no obvious defects are observed in the modified samples [19]. Thus we conclude that single acid leaching method cannot meet the requirements. Zeolite treated by $\left(\mathrm{NH}_{4}\right)_{2} \mathrm{SiF}_{6}$ possesses high crystallinity while it has little amount of mesopores [20, 21]. The EFAL can be removed efficiently whereas the silica deposits on the outer surface, leading to a less mesoporous structure [22]. Up to date, the aforementioned modification method still experiences more or less problems and challenges, e.g. unsatisfying hydrothermal stability, poor mesoporous structure and harsh operation conditions. Exploring a facile and efficient approach to modify commercial USY zeolite is still challenging.

Herein, we developed a combined modification method of USY zeolite using citric acid (CA) and ammonium fluosilicate (AFS). The CA remove aluminum by coordination reaction to create abundant secondary pores. The $\mathrm{F}^{-}$from AFS can insert into the framework during the dealumination, leading to a high crystallinity of the modified USY zeolite. In addition, the abundant secondary pores provide rapid diffusion channels for $\mathrm{F}^{-}$, which can avoid the deposition of silica species on the surface of USY.The CA and AFS modified USY zeolite (CFUSY) presentes a higher secondary pore volume, appropriate acidic properties, good hydrothermal stability and excellent catalytic performance.

\section{Experimental section}

\section{Sample preparation}

Firstly, CA solution and AFS solution with different concentrations were prepared. Then a fixed quantity of $12 \mathrm{~g}$ CUSY zeolites and different amount of CA solution were put into a $250 \mathrm{ml}$ three-neck polytetrafluoroethylene reactor. Subsequently the reactor was transferred into a water bath with a certain temperature. Ammonium fluosilitcate solution was dropwise added into the reactor when the system reached setting temperature. The modification was completed after a certain time. Afterwards, the products were filtrated and washed with distilled water. At last the product was obtained after dried in a $110{ }^{\circ} \mathrm{C}$ oven overnight.

\section{Sample characterization}

Nitrogen adsorption measurements were performed on a TriStar 3000 analyzer (Micromeritics, USA) to obtain specific surface area and pore structure parameters of the as-prepared samples. The total surface area was calculated using BET (Brunauer-Emmett-Teller) method. The mesopore surface area, mesopore volumes and pore size distribution were obtained from the desorption branch by a BJH (Barret-Joyner-Halenda) method. Si/Al ratio, cell parameters and crystallinity were characterized by $\mathrm{X}$-ray diffraction (XRD) analysis (X'Pert PRO MPD, Holland). The acidy property of the sample was measured by FT-IR (Nicolet 6700, USA) using pyridine as probe molecule. $\mathrm{NH}_{3}$-temperature programmed desorption $\left(\mathrm{NH}_{3}-\mathrm{TPD}\right)$ characterization was carried out on CHEMBET-3000 TPR/ TPD Chemisorption analyzer (Quatachrome Instrument, USA). $\mathrm{NH}_{3}$-TPD curves were performed in the range of $50-700{ }^{\circ} \mathrm{C}$ with a heating rate of $15{ }^{\circ} \mathrm{C}$ per minute. The ammonia was adsorbed at room temperature while it was desorbed at $120{ }^{\circ} \mathrm{C}$ for $1 \mathrm{~h}$ in flowing pure nitrogen.

\section{Results and discussions}

Investigation of operation conditions

Secondary pores are important for preventing secondary cracking when USY are used in the hydrocracking. However, the mesoporous structure of the modified USY zeolite is affected by a series of factors including the concentration of CA and AFS, the volume ratio of CA and AFS, adding rate of AFS, reaction time and temperature single-factor experiment. Therefore, we investigated the optimum operation condition by a single-factor experiment using 
Table 1 The secondary pore volume of modified USY zeolite in different operation conditions

\begin{tabular}{|c|c|c|c|c|c|c|c|}
\hline Sample & $\begin{array}{l}\text { Concentration } \\
\text { of } \mathrm{CA}, \mathrm{mol} / \mathrm{L}\end{array}$ & $\begin{array}{l}\text { Adding rate, } \\
\mathrm{d} / \mathrm{min}^{\mathrm{a}}\end{array}$ & $\begin{array}{l}\text { Reaction } \\
\text { time, } \mathrm{h}\end{array}$ & $\begin{array}{l}\text { Volume } \\
\text { ratio }^{\mathrm{b}}\end{array}$ & $\begin{array}{l}\text { Concentration } \\
\text { of AFS, mol/L }\end{array}$ & $\begin{array}{l}\text { Reaction } \\
\text { temperature, }{ }^{\circ} \mathrm{C}\end{array}$ & $\begin{array}{l}\text { Secondary pore } \\
\text { volume, } \mathrm{cm}^{3} / \mathrm{g}\end{array}$ \\
\hline CF-1 & 0.2 & 20 & 3 & 1.0 & 0.1 & 70 & 0.18 \\
\hline CF-2 & 0.1 & 20 & 3 & 1.0 & 0.1 & 70 & 0.18 \\
\hline CF-3 & 0.15 & 20 & 3 & 1.0 & 0.1 & 70 & 0.19 \\
\hline CF-4 & 0.25 & 20 & 3 & 1.0 & 0.1 & 70 & 0.17 \\
\hline CF-5 & 0.15 & 15 & 3 & 1.0 & 0.10 & 70 & 0.16 \\
\hline CF-6 & 0.15 & 25 & 3 & 1.0 & 0.10 & 70 & 0.17 \\
\hline CF-7 & 0.15 & 30 & 3 & 1.0 & 0.10 & 70 & 0.16 \\
\hline CF-8 & 0.15 & 20 & 2 & 1.0 & 0.10 & 70 & 0.16 \\
\hline CF-9 & 0.15 & 20 & 4 & 1.0 & 0.10 & 70 & 0.15 \\
\hline CF-10 & 0.15 & 20 & 5 & 1.0 & 0.10 & 70 & 0.19 \\
\hline CF-11 & 0.15 & 20 & 3 & 0.5 & 0.10 & 70 & 0.17 \\
\hline CF-12 & 0.15 & 20 & 3 & 1.5 & 0.10 & 70 & 0.16 \\
\hline CF-13 & 0.15 & 20 & 3 & 2.0 & 0.10 & 70 & 0.17 \\
\hline CF-14 & 0.15 & 20 & 3 & 1.0 & 0.20 & 70 & 0.20 \\
\hline CF-15 & 0.15 & 20 & 3 & 1.0 & 0.05 & 70 & 0.17 \\
\hline CF-16 & 0.15 & 20 & 3 & 1.0 & 0.15 & 70 & 0.19 \\
\hline CF-17 & 0.15 & 20 & 3 & 1.0 & 0.20 & 90 & 0.25 \\
\hline CF-18 & 0.15 & 20 & 3 & 1.0 & 0.20 & 80 & 0.22 \\
\hline CF-19 & 0.15 & 20 & 3 & 1.0 & 0.20 & 60 & 0.20 \\
\hline
\end{tabular}

a $\mathrm{d} / \mathrm{min}=$ drop/minute

${ }^{\mathrm{b}}$ volume ratio $=$ volume of $\mathrm{CA} /$ volume of $\mathrm{AFS}$

mesopore volume as criterion. The modification condition and results are listed in Table 1.

As shown in the table, with the increase of the concentration of CA solution, the secondary pore volume of modified USY zeolite increases firstly and then decreases. This is because the alumina species can be removed more effectively at higher concentration of CA solution. However, the coordination compound formed by $\mathrm{CA}$ and alumina will plug the channel if the concentration of $\mathrm{CA}$ solution is too high. So we select $0.15 \mathrm{~mol} / \mathrm{L}$ as the best concentration of CA. Then we investigated the effect of adding rate on the secondary pore volume. It is obvious that the modified USY zeolite possesses the highest secondary pore volume of $0.19 \mathrm{~cm}^{3} / \mathrm{g}$ when the adding rate of AFS solution is $20 \mathrm{~d} / \mathrm{min}$. The framework alumina can be removed rapidly with the help of AFS. But if AFS is added too fast, there will be not enough time to remove the alumina species in the channel, leading to a decrease of pore volume. Similarly, the alumina species can be removed most efficiently when the volume ratio and concentration of AFS are 1.0 and $0.20 \mathrm{~mol} / \mathrm{L}$, respectively. In addition, the reaction time was also studied. It is interesting that the modified USY zeolite has the highest secondary pore volume when it was modified for 3 or $5 \mathrm{~h}$. We select $3 \mathrm{~h}$ as the best operation time in view of economy and efficiency. Furthermore, the modifications of USY zeolite are also performed at different temperature. The secondary pore volume of modified USY zeolite increase with the increase of reaction temperature, which is to be expected. However, the framework structure of USY zeolite will be destroyed heavily at high temperature caused by the corrosion of $\mathrm{F}^{-}$[23], leading to a rapid decrease of crystallinity. So we are more inclined tomodify USY zeolite at $60{ }^{\circ} \mathrm{C}$ even it will result in the lowest secondary pore volume. The USY zeolite modified at $60{ }^{\circ} \mathrm{C}$ present a higher crystallinity of $76.5 \%$ than the others. According to the results of single-factor experiment, we can conclude that the modification of USY zeolite has the best performance when the concentration of CA, the concentration of AFS, the volume ratio, adding rate of $\mathrm{AFS}$, reaction time and temperatureare 0.15 , $0.20 \mathrm{~mol} / \mathrm{L}, 1.0,20 \mathrm{~d} / \mathrm{min}, 3 \mathrm{~h}$ and $60{ }^{\circ} \mathrm{C}$, respectively.

\section{Characterization and discussion}

CFUSY was prepared at the optimal modification condition.

\section{Surface area and pore size distribution of modified USY}

$\mathrm{N}_{2}$ adsorption-desorption isotherms determined at $77 \mathrm{~K}$ and the pore size distribution of the prepared samples are 


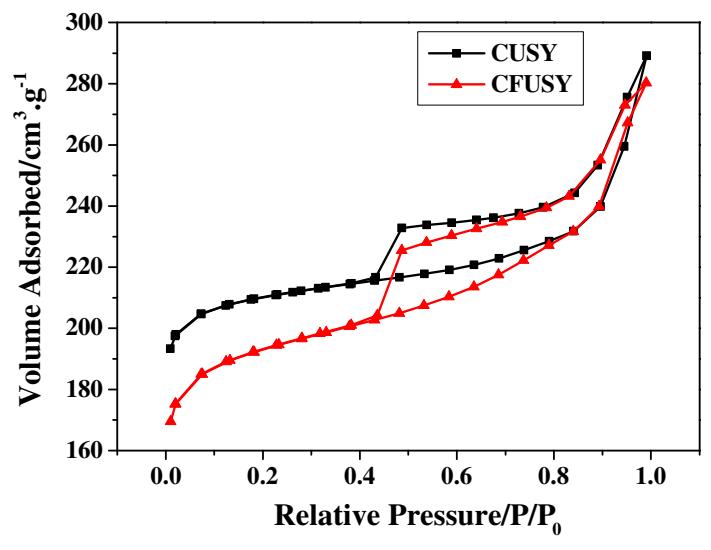

Fig. $1 \mathrm{~N}_{2}$ adsorption-desorption isotherms of modified USY

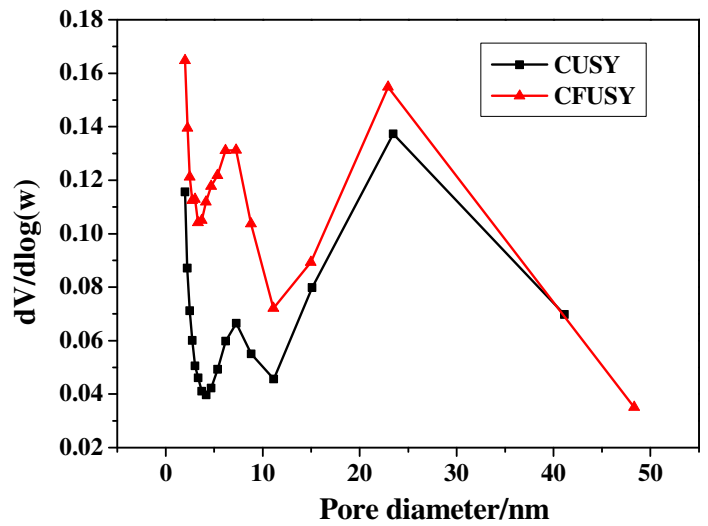

Fig. 2 Pore size distributions of modified USY

shown in Figs. 1 and 2. Both CUSY and CFUSY present a type IV adsorption isotherm with a $\mathrm{H} 2$ hysteresis loop ranging from relative pressure of $0.43-1.0$, which is the characteristic of abundant mesopores. In addition, the specific surface area of USY decreases from 641 to $594 \mathrm{~m}^{2} / \mathrm{g}$ while the mesopore area increases from 99 to $150 \mathrm{~m}^{2} / \mathrm{g}$ after modification. Similarly, the secondary pore volume increases from 0.17 to $0.20 \mathrm{~cm}^{3} / \mathrm{g}$ (Table 2). The EFAL is removed by citric acid via coordination effect while some framework aluminum is removed by $\mathrm{F}^{-}$, leading to the increase of secondary pore volume. The destruction of framework caused by AFS makes some micropores connect with each other to form secondary pores. The pore size distribution (Fig. 2) shows that modified USY zeolites possess intensive distribution of secondary pores which are centralized at about 8.0 and $23 \mathrm{~nm}$.

\section{Acid characterization of modified USY}

The acid properties of the samples were characterized by pyridine adsorption FT-IR and $\mathrm{NH}_{3}$-TPD. It is found that there are three bands for each sample in the FT-IR spectra (Fig. 3). The bands at 1,442 and $1,548 \mathrm{~cm}^{-1}$ represent the characteristic adsorption of pyridine on Lewis (L) and Brøsted (B) acidic sites, respectively. While band at $1,490 \mathrm{~cm}^{-1}$ is assigned to the combined effect of B and L acidic sites [24]. Compared with CUSY, CFUSY presents higher intensity at $1,442 \mathrm{~cm}^{-1}$, indicating the increment of $\mathrm{L}$ acidic sites for the modified USY. Besides, the weaker peak assigned to $\mathrm{B}$ acid demonstrates the decrease of $\mathrm{B}$ acid sites. In addition, the acid strength was measured by $\mathrm{NH}_{3}$-TPD. All curves present two peaks at 200 and $450{ }^{\circ} \mathrm{C}$ (Fig. 4). Interestingly, the $200{ }^{\circ} \mathrm{C}$ peak of CFUSY shift to higher temperature, indicating that the acid strength of weak acid increased. According to the peak area, the acid amount of both strong acid and weak acid decreases due to the remove of alumina. However, the amount of weak acid decreases much more than medium acid, leading to an increase of proportion of medium acid.

\section{$X$-ray diffraction characterization}

As shown in Fig. 5, CFUSY possesses obvious diffraction peaks of faujasite, indicating a good crystallinity. The crystal structure parameters of as-prepared samples are listed in the Table 3. It shows that the $\mathrm{Si} / \mathrm{Al}$ ratio of CFUSY are more than twice higher than that of CUSY. The cell parameter becomes smaller and crystallinity decreases after modification. The improvement of $\mathrm{Si} / \mathrm{Al}$ ratio is caused by the dealumination and silicon reinsertion. Hydrated silica can insert into the framework during the dealumination process, which can avoid the collapse of skeleton caused by dealumination and improve the $\mathrm{Si} / \mathrm{Al}$ ratio. So the modified USY zeolite presents a high crystallinity of $76.5 \%$ even at a high $\mathrm{Si} / \mathrm{Al}$ of 25.7 . Owing to the replacement of aluminum by silicon, unit cell parameters become smaller since $\mathrm{Si}-\mathrm{O}$ bond length is shorter than $\mathrm{Al}-\mathrm{O}$ bond.

Table 2 Texture properties of modified USY

\begin{tabular}{lllllll}
\hline Sample & $\begin{array}{l}\text { BET surface } \\
\text { area, } \mathrm{m}^{2} / \mathrm{g}\end{array}$ & $\begin{array}{l}\text { Micropore } \\
\text { area, } \mathrm{m}^{2} / \mathrm{g}\end{array}$ & $\begin{array}{l}\text { Secondary pore } \\
\text { area, } \mathrm{m}^{2} / \mathrm{g}\end{array}$ & $\begin{array}{l}\text { Total volume, } \\
\mathrm{cm}^{3} / \mathrm{g}\end{array}$ & $\begin{array}{l}\text { Micropore volume, } \\
\mathrm{cm}^{3} / \mathrm{g}\end{array}$ & $\begin{array}{l}\text { Secondary pore } \\
\text { volume, } \mathrm{cm}^{3} / \mathrm{g}\end{array}$ \\
\hline CUSY & 641 & 570 & 99 & 0.45 & 0.29 & 0.17 \\
CFUSY & 594 & 479 & 150 & 0.43 & 0.25 & 0.20 \\
\hline
\end{tabular}




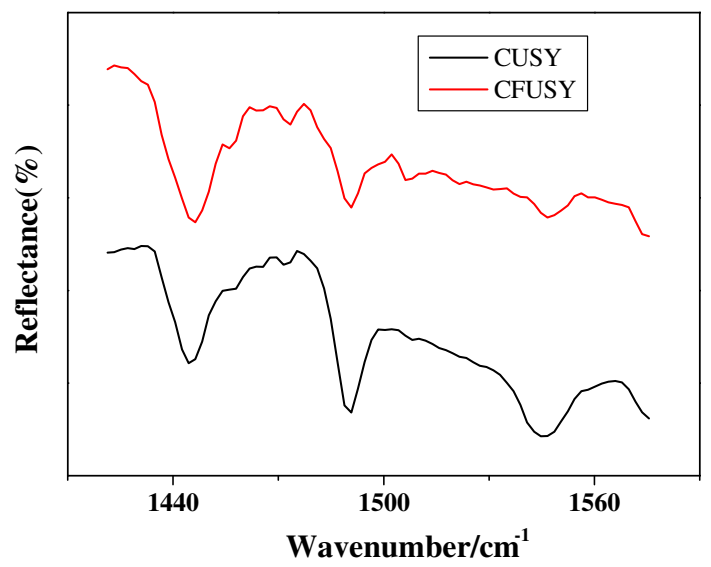

Fig. 3 pyridine adsorption FT-IR diffuse reflection spectras of USY

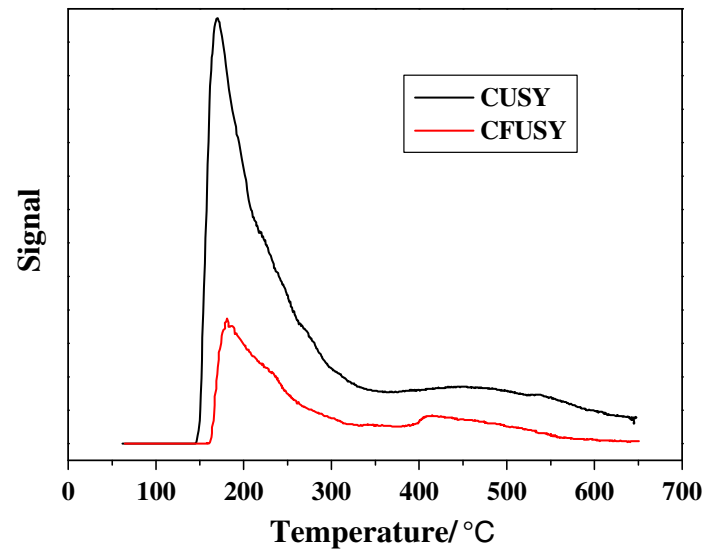

Fig. $4 \mathrm{NH}_{3}$-TPD profiles of USY

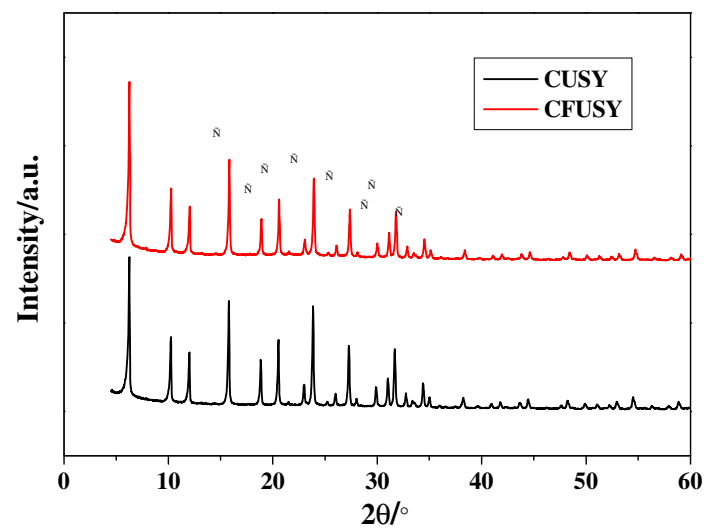

Fig. 5 The XRD pattern of USY zeolite

\section{Hydrothermal stability characterization}

The modified USY zeolites were treated at $600{ }^{\circ} \mathrm{C}$ with the existence of vapour for $4 \mathrm{~h}$. Then the specific surface area and pore structure parameters were measured to study its hydrothermal stability. The results listed in Table 4 demonstrate that the BET surface area and micropore area slightly decrease after hydrothermal treatment, whereas the secondary pore area and volume increase. This is mainly because the micropores are destroyed after a long-term treatment with steam and then the mesopores form with the connection of micropores. Furthermore, the steam can also remove the framework alumina at high temperature, giving rise to mesopores. Generally, the modified USY zeolites has a good hydrothermal stability under $600{ }^{\circ} \mathrm{C}$ which is much higher than the hydrocracking reaction temperature.

\section{Evaluation of catalyst}

According to the $75.0 \%$ conversion of $>350{ }^{\circ} \mathrm{C}$ feedstock (Table 5), CFUSY exhibits excellent hydrocracking performance. The $140-370{ }^{\circ} \mathrm{C}$ middle distillate yield of hydrocracking product is $67.78 \%$, and at the same time, the selectivity to middle distillate could reach up to $80.76 \%$. Compared with CUSY, the yield and selectivity were increased by 7.36 and $4.38 \%$, respectively. The results demonstrate that combined modification of ultrastable Y zeolites using CA solution and AFS solution can meet the need of productive middle distillate in the industrial unit, which predicts it may be a potential industrialized method of $\mathrm{Y}$ zeolites modification.

\section{Conclusion}

A combined modification of commercial ultra-stable $\mathrm{Y}$ zeolite using citric acid and ammonium fluosilicate has

Table 3 Crystal structural parameters of USY zeolite

\begin{tabular}{|c|c|c|c|}
\hline Sample & $\begin{array}{l}\text { Degree of crystallinity } \\
\left(\mathrm{C}_{\mathrm{RX}} / \%\right)\end{array}$ & $\begin{array}{l}\text { Cell parameters }\left(\mathrm{a}_{0} /\right. \\
\mathrm{nm})\end{array}$ & $\begin{array}{l}\mathrm{Si} / \mathrm{Al} \\
\text { ratio }\end{array}$ \\
\hline CUSY & 84.0 & 24.452 & 10.8 \\
\hline CFUSY & 76.5 & 24.311 & 25.7 \\
\hline
\end{tabular}

Table 4 Surface area and pore volume of modified USY before and after hydrothermal treatment

\begin{tabular}{lllllll}
\hline Sample & $\begin{array}{l}\text { BET surface } \\
\text { area, } \mathrm{m}^{2} / \mathrm{g}\end{array}$ & $\begin{array}{l}\text { Micropore } \\
\text { area, } \mathrm{m}^{2} / \mathrm{g}\end{array}$ & $\begin{array}{l}\text { secondary pore } \\
\text { area, } \mathrm{m}^{2} / \mathrm{g}\end{array}$ & $\begin{array}{l}\text { Total volume, } \\
\mathrm{cm}^{3} / \mathrm{g}\end{array}$ & $\begin{array}{l}\text { Micropore } \\
\text { volume, } \mathrm{cm}^{3} / \mathrm{g}\end{array}$ & $\begin{array}{l}\text { Secondary pore } \\
\text { volume, } \mathrm{cm}^{3} / \mathrm{g}\end{array}$ \\
\hline CFUSY & 594 & 479 & 150 & 0.43 & 0.25 & 0.20 \\
CFUSY-SR & 567 & 441 & 172 & 0.40 & 0.23 & 0.24 \\
\hline
\end{tabular}


Table 5 Hydrocracking performance of catalyst

\begin{tabular}{lcc}
\hline Products distribution, $\%$ & CFUSY & CUSY \\
\hline HK- $140{ }^{\circ} \mathrm{C}$ & 16.15 & 18.68 \\
$140-370{ }^{\circ} \mathrm{C}$ & 67.78 & 60.42 \\
$>370{ }^{\circ} \mathrm{C}$ & 15.01 & 20.16 \\
Loss & 1.06 & 0.74 \\
Conversion of $>350{ }^{\circ} \mathrm{C}$ feedstock, $\%$ & 75.0 & 75.0 \\
Selectivity to middle distillate, $\%$ & 80.76 & 76.38 \\
\hline
\end{tabular}

Conversion $=\left(1->350{ }^{\circ} \mathrm{C}\right.$ fraction of production $/>350{ }^{\circ} \mathrm{C}$ fraction of feed oil) $\times 100 \%$

Yield $=\left(140-370{ }^{\circ} \mathrm{C}\right.$ middle distillates fraction of production $) \times$ $100 \%$

Middle distillates selectivity $=\left(140-370{ }^{\circ} \mathrm{C}\right.$ fraction of production/ $<370{ }^{\circ} \mathrm{C}$ fraction of production) $\times 100 \%$

been successfully developed. The optimum operation condition is investigated via a single-factor experiment. The modified USY zeolite under the optimum technological conditions presents an enhanced secondary pore volume and appropriate acid distribution as well as good crystallinity. When the modified USY zeolite is used in hydrocracking, it presents an excellent middle distillate selectivity.

Acknowledgments This work was financially supported by Petro China Refinery Catalyst Key Project (2010E-1903) and Key Program of NSFC (U1362202).

Open Access This article is distributed under the terms of the Creative Commons Attribution License which permits any use, distribution, and reproduction in any medium, provided the original author(s) and the source are credited.

\section{References}

1. Hassan A, Ahmed S, Ali MA, Hamid H, Inui T (2001) A comparison between $\beta$ - and USY-zeolite-based hydrocracking catalysts. Appl Catal A 220:59-68

2. Gosselink J, Stork W (1997) Coping with catalyst deactivation in hydrocracking: catalyst and process development. Ind Eng Chem Res 36:3354-3359

3. Sullivan R and Meyer J, presented at the ACS Symposium Series, 1975 (unpublished)

4. Ogura M, Shinomiya S-Y, Tateno J, Nara Y, Nomura M, Kikuchi E, Matsukata M (2001) Alkali-treatment technique -new method for modification of structural and acid-catalytic properties of ZSM-5 zeolites. Appl Catal A 219:33-43

5. Sato K, Nishimura Y, Honna K, Matsubayashi N, Shimada H (2001) Role of HY zeolite mesopores in hydrocracking of heavy oils. J Catal 200:288-297

6. Chang X-W, He L-F, Liang H-N, Liu X-M, Yan Z-F (2010) Screening of optimum condition for combined modification of ultra-stable Y zeolites using multi-hydroxyl carboxylic acid and phosphate. Catal Today 158:198-204
7. Mcdaniel C, Maher P (1968) Molecular sieves. Society of Chemical Industry, London 186

8. Sasaki Y, Suzuki T, Takamura Y, Saji A, Saka H (1998) Structure analysis of the mesopore in dealuminated zeolite $\mathrm{Y}$ by high resolution TEM observation with slow scan CCD camera. J Catal 178:94-100

9. Stach H, Lohse U, Thamm H, Schirmer W (1986) Adsorption equilibria of hydrocarbons on highly dealuminated zeolites. Zeolites 6:74-90

10. Gola A, Rebours B, Milazzo E, Lynch J, Benazzi E, Lacombe S, Delevoye L, Fernandez C (2000) Effect of leaching agent in the dealumination of stabilized Y zeolites. Microporous Mesoporous Mater 40:73-83

11. Cruz J, Corma A (1989) Framework and extra-framework aluminium distribution in $\left(\mathrm{NH}_{4}\right)_{2} \mathrm{~F}_{6}$ Si-dealuminated $\mathrm{Y}$ zeolites: relevance to cracking catalysts. Appl catal 50:287-293

12. Lónyi F, Lunsford JH (1992) The development of strong acidity in hexafluorosilicate-modified Y-type zeolites. J Catal 136:566-577

13. Kubelková L, Seidl V, Nováková J, Bednárová S, Jírů P (1984) Properties of Y-type zeolites with various silicon/aluminium ratios obtained by dealumination with silicon tetrachloride. Distribution of aluminium and hydroxyl groups and interaction with ethanol. J Chem Soc Faraday Trans 1: Phys Chem Condens Phases 80:1367-1376

14. Anderson MW, Klinowski J (1986) Zeolites treated with silicon tetrachloride vapour. IV. Acidity Zeolites 6:455-466

15. Dong S-T, Li X-W, Li D-D, Shi Y-H, Nie H, Kang X-H (2002) Study on the formation of mesopore during hydrothermal dealumination of $\mathrm{Y}$ zeolite. ACTA PHYSICOCHIMICA SINICA 18:201-206

16. Yoshida A, Inoue K, Adachi Y (1991) Hydrothermal stability of US-Ex. Zeolites 11:223-231

17. Giudici R, Kouwenhoven H, Prins R (2000) Comparison of nitric and oxalic acid in the dealumination of mordenite. Appl Catal A 203:101-110

18. Leiras Gomes A, Falabella S, Aguiar E, Cabral Menezes S, Cardoso D (1997) Influence of combined acid treatment on physico-chemical characteristics of ultrastable zeolite $\mathrm{Y}$ and on its catalytic properties in the disproportionation of ethylbenzene. Appl Catal A 148:373-385

19. Liu X-M, Yan Z-F (2001) Optimization of nanopores and acidity of USY zeolite by citric modification. Catal Today 68:145-154

20. López-Fonseca R, De Rivas B, Gutiérrez-Ortiz J, Aranzabal A, González-Velasco J (2003) Enhanced activity of zeolites by chemical dealumination for chlorinated VOC abatement. Appl Catal B 41:31-42

21. Matharu A, Gladden L, Carr S (1995) Characterisation and catalytic properties of dealuminated zeolite-Y: a comparison of ammonium hexafluorosilicate and hydrothermal treatments. Stud Surf Sci Catal 94:147-154

22. Wang Q-L, Torrealba M, Giannetto G, Guisnet M, Perot G, Cahoreau M, Caisso J (1990) Dealumination of Y zeolite with ammonium hexafluorosilicate: a SIMS-XPS study of the aluminum distribution. Zeolites 10:703-706

23. Cañizares P, Carrero A (2003) Dealumination of ferrierite by ammonium hexafluorosilicate treatment: characterization and testing in the skeletal isomerization of n-butene. Appl Catal A 248:227-237

24. Lercher J, Rumplmayr G (1986) Controlled decrease of acid strength by orthophosphoric acid on ZSM5. Appl catal $25: 215-222$ 